\title{
RGN-Verslag oor godsdiens, tussengroepverhoudinge en maatskaplike verandering in Suid-Afrika*
}

\author{
PJ van der Merwe
}

\begin{abstract}
The HSRC Report on religion, intergroup relations and social change in South Africa

This article deals with the HSRC Report Religion, intergroup relations and social change in South Africa of 1985. The report is found to be well researched. A basic statement thereof is that religion functions in an ambivalent manner: It may transcend group interests for the sake of broader or national interests and thus facilitate reconciliation or it may become a captive of group interests and by legitimising group perceptions and claims, contribute to intergroup tension. Despite the Committee's claim to a scientific approach to religion, the report displays a natural theological aspect.
\end{abstract}

Die Raad vir Geesteswetenskaplike Navorsing het gedurende die tweede helfte van 1985 begin om die resultate vry te stel van sy vierjaarlange ondersoek na tussengroepverhoudinge in Suid-Afrika. Die hoofverslag is aan die begin van Julie 1985 vrygestel en het dadelik polemiek uitgelok. Die verslag van die Werkkomitee Godsdiens wat gehandel het oor godsdiens, tussengroepverhoudinge en maatskaplike verandering is in die loop van die tweede helfte van 1985 vrygestel en het ook nie polemiek vrygespring nie. Dit is laasgenoemde verslag wat in hierdie artikel van naderby bekyk word.

By die bespreking van die verslag staan ' $n$ mens voor die probleem van die omvangrykheid daarvan en die rykdom van gegewens daarin vervat. Dit is uiteraard onmoontlik om elke aspek aan die orde te stel of reg daaraan te laat geskied, en gevolglik word gekonsentreer op daardie aspekte wat as die belangrikste ervaar word.

\footnotetext{
- Literatuurverwysings en aanhalings uit die Engelse uitgawe, Religion, intergroup relations and social change in South Africa. RGN: Pretoria.
} 


\section{SAMESTELLING VAN WERKKOMITEE}

Die Werkkomitee het onder die voorsitterskap van die bekende prof GC Oosthuizen van die Universiteit van Durban-Westville gestaan en het ook die volgende lede gehad: proff CJ Alant, DJ Bosch, GD Cloete, CW Cook, JW de Gruchy, JJF Durand, JA Heyns, MP Krishna, BC Lategan, SS Maimela, B Spoelstra, TD Verryn, drr F Edwards, B Goba, rabbi I Goss en ds J Mettler. GD Cloete en SS Maimela het later bedank, terwyl TD Verryn skielik oorlede is. Hierop is prof JK Coetzee en $\mathrm{dr} \mathrm{JH}$ Hofmeyr genooi om hulle by die komitee aan te sluit.

\section{INHOUD VAN VERSLAG}

Die verslag beslaan 227 bladsye en is in die volgende hoofstukke verdeel:

Hoofstuk 1 Inleiding: geskiedenis en bedoeling van die verslag; grensomskrywing; die begrip godsdiens of religie.

Hoofstuk 2 Patrone van godsdienstige aanhang en verwagtinge in Suid-Afrika.

Hoofstuk 3 Teenstrydige perspektiewe en godsdiens in 'n heterogene samelewing.

Hoofstuk 4 Aktualiteite en die huidige debat binne religieuse verband.

Hoofstuk 5 Bevindinge en aanbevelings.

Hierna volg die aanhangsels wat uit literatuurlyste en verslae van toegespitste studies bestaan.

\section{NAVORSERS}

Die volgende persone het navorsingsprojekte uitgevoer waarop die verslag gesteun het: Proff D Crafford, JS Cumpsty, DA du Toit, BA Müller, K Nürnberger, GC Oosthuizen, PJ Robinson, drr JH Hofmeyr, JJ Kritzinger, LM Muntingh en mej J Grobbelaar.

'n Probleem wat ruiterlik in die verslag erken word, is dat empiriese studies hoofsaaklik op die stedelike konteks, veral die Durbanse metropolitaanse gebied en Kaapse Vlakte, gekonsentreer het en dat die platteland nie genoeg aandag ontvang het nie. 


\section{HANTERING VAN METODOLOGIESE PLURALITEIT}

Reeds in die eerste hoofstuk word erken dat die uiteenlopende metodologiese benaderings wat navorsingsprojekte en -resultate geopenbaar het en die breë veld wat gedek is, die werk van die komitee bemoeilik het. Een van die pogings om die probleme te bowe te kom, was om materiaal uit die verskeie studies te selekteer en te abstraheer en dit in die verslag van die komitee te gebruik. So is gepoog om eenheid en sintese in die verslag te verkry. Die afsonderlike studies wat die meeste gebruik is, is ò in saamgevatte vorm ò net so as aanhangsels aangeheg.

Dit spreek vanself dat so 'n seleksie en abstraksie 'n eie bedoeling, idee en metodologiese benadering moet weerspieël wat nie noodwendig met dié van elke bydraende studie ooreenstem nie. Die verslag is dus ' $n$ eie skepping van die komitee waarin gekies is vir ' $n$ bepaalde standpunt en metodologiese benadering.

In hierdie verband maak die verslag ook melding van die probleem wat ontstaan wanneer 'n multidissiplinêre studie soos dié aangepak word. Verskillende dissiplines, soos sosiologie, volkekunde en teologie, elkeen met sy eie metodologiese inslag, word betrek. Uiteindelik het die komitee vir die 'sosiaalwetenskaplike benadering' gekies, omdat waarskynlik geoordeel is dat die verskillende insette die beste so verdiskonteer sou kon word. Of die inslag en impak van die verslag as objektief wetenskaplik getipeer kan word, is egter te betwyfel. Basies word ' $n$ empiries-deskriptiewe benadering gevolg, maar die styl waarmee bevindinge betoog en meegedeel word, getuig van sosio-politiese, -teologiese betrokkenheid.

lets wat nie eksplisiet in die verslag genoem of erken word nie, maar tog onder oë gesien moet word, is die feit dat reeds die opdrag aan die komitee 'n sosio-politieke inslag gehad het en dat dit uit die staanspoor dus om meer as wetenskaplike motiewe gegaan het. Dit blyk ook duidelik uit die verslag se eksistensiële betrokkenheid by en bekommernis oor die Suid-Afrikaanse situasie. So iets moet teruggaan op 'n bepaalde visie van die Suid-Afrikaanse situasie wat op sy beurt 'n bepaalde ideologiese element sal bevat.

\section{KONSENSUS EN UITEENLOPENDHEID VAN OPINIES}

Die verslag erken ook verdere leemtes en beperkinge. Die belangrikste het te doen met die samestelling van die komitee. Ten spyte van po- 
gings om 'n breë verteenwoordigende komitee saam te stel, word erken dat die komitee op die ou end bestaan het uit persone wat in ' $n$ groot mate saamgestem het oor die aangeleenthede wat ter sake was en die slotsom waartoe bevindinge gelei het. Die opinie word nogtans uitgespreek dat die komitee verteenwoordigend genoeg was en sy konsensus derhalwe ook relevant genoeg.

Hierdie aanspraak word enigermate ondermyn deur die volgende erkenning: '... however much the committee may have striven for objectivity ... there is ultimately no neutral position on the kind of issues with which the report deals' (bl 8). Daar word trouens gevra of 'n breë verteenwoordigende komitee prakties haalbaar sou wees en of dit enige konsensus sou kon bereik. Die vraag is natuurlik of so 'n komitee noodwendig konsensus moet bereik gesien die legio standpunte, ideologiese en teologiese invalshoeke en dies meer wat 'n studie soos dié kan beïnvloed. Strewe na konsensus kan dié werklikheid onderdruk en die uiteindelike relevansie van bevindinge aantas. Aan die ander kant is praktiese haalbaarheid ' $n$ oorweging wat nie sonder meer afgemaak kan word nie.

Hoewel dit nie gesê word nie, gee die verslag dus ook by implikasie toe dat dieselfde soort navorsing ook met ander uitgangspunte en basiese opvattinge uitgevoer kan word en dat daar dan moontlik tot ander bevindings gekom sal kan word.

Aspekte van genoemde konsensus word voorts soos volg gestel:

- Die huidige tussengroepsituasie in Suid-Afrika het kritiek geword.

- Gesonde en geldige godsdiens behoort goeie tussenpersoonlike en tussengroepverhoudinge in die hand te werk.

\section{GODSDIENSOPVATTING}

Daar is min onderwerpe waaroor opinies so verdeeld is as die antwoord op die vraag wat godsdiens is. Die verslag gee blyke van kennisname van die debat en teoretiese kwessies daaroor, maar gee dan toe dat 'n praktiese benadering uiteindelik gevolg is. Hiermee moet 'n mens simpatie hê. Aan die ander kant is dit juis dié klein roertjie wat die skip stuur en daarom kyk ons nou in besonderhede daarna.

'n Belanghebbende uitspraak hieroor is die volgende: 'Fortunately, a broadly common understanding of what religion ought to be seems to have emerged in the research done for this report. While not a definition, it provides a basic framework from within which the nature and 
actual functions of religion in South Africa can be understood' (bl 9). Die sleutelwoorde is: '. . . what religion ought to be ...', waarmee toegegee word dat ons hier nie met 'n suiwer deskriptief-interpretatiewe godsdiensopvatting te doen het nie, maar 'n normatiewe. Dit strook ook met die algemene trant van die verslag: Onder die analitiese en beskrywende klink 'n toon van evaluerende, normatief-normerende spreke wat ooreenstem met die perspektief wat uit die volgende woorde blyk: 'The rationale for religion is the healing of social relations' (bl 8).

Hierdie standpunt, soos uitgewerk in hoofstuk 2, word in die laaste hoofstuk soos volg saamgevat (bl $101 \mathrm{vv}$ ):

- Daar is sekere ideale funksies van godsdiens. Hulle is: (a) Die integrasie van individu en gemeenskap in terme van lewenssin en -oriëntasie, van werklikheidsin en gemeenskaplike waardes. (b) Die daarstelling van motiveringsentimente en oorkoepelende geloofsopvattings en -waardes.

- Godsdiens mis sy doel wanneer hierdie ideale funksies ontbreek, byvoorbeeld wanneer genoemde integrasie op 'n te beperkte skaal plaasvind en motivering sodanig verloop (naamlik groepsgeöriënteerd) dat die (groter) samelewing benadeel word.

Uit hoofstuk 2 blyk dat hierdie standpunte voorgee om op empiriese bevindings terug te gaan. Die waarde van die ingesamelde inligting lê daarin dat dit lyk of baie mense in Suid-Afrika meen dat die gevestigde godsdienste, gemeet aan die 'ideale funksies van godsdiens', teleurstellend vertoon (bl 29). Dit moet egter onthou word dat met die opstelling van die vraelyste en die interpretasie daarvan van 'n bepaalde godsdiensopvatting uitgegaan moes gewees het en dié skyn funksionalisties te wees.

In die teoretiese verantwoording van die godsdiensopvatting waarmee gewerk is (bl $9 \mathrm{vv}$ ), word uiteraard gekonsentreer op die verhouding tussen godsdiens en maatskappy. Die volgende aspekte word behandel:

\section{- Godsdiens en werklikheidsrelevansie}

Godsdiens word beskryf as dit wat die lewe (in geheel beskou) in een of ander vorm van perspektief plaas. Dit dra waardes waarmee die werklikheid (wat die praktiese, sosiale, ekonomiese en politieke werk- 
likheid insluit) verstaan word. Dit motiveer tot gesonde verhoudinge met die werklikheid en dus ook tot gesonde tussenpersoonlike- en tussengroepverhoudinge. ' $n$ Godsdiensgroep is 'n groep mense wat hierdie waardes deel en dieselfde basiese lewens- en werklikheidsvisie het. Die relevansie van 'n godsdiens hang af daarvan of sy aanhangers die waardes daarvan ervaar as in ooreenstemming met hulle daaglikse ervaring van die lewe. ' $n$ Statiese godsdiens is onmoontlik, omdat daar voortdurend interaksie tussen 'n godsdiens en sy aanhangers is. Institusionalisering het ' $n$ manier om godsdiens nogal staties te maak en dit kan daartoe lei dat so 'n godsdiens nie altyd relevant is nie. 'n Irrelevante godsdiens is dus een wat verband verloor het met die manier waarop sy aanhangers die lewe en werklikheid ervaar.

Die probleem wat 'n mens hier kan aanstip, is dat daar ietwat ongenuanseerd oor relevansie gepraat word. 'n Godsdiens mag irrelevant wees in terme van die sosio-politieke situasie van die dag, maar'n dieper werklikheidsrelevansie vir sy aanhangers inhou. So noem die verslag in hoofstuk 2 'n vreemde spanning in die godsdienstige verwagtinge van nie-blanke respondente. Terwyl die meeste van hulle saamgestem het dat godsdienstige bewegings strukturele bevryding moet help bevorder, het 'n aansienlike persentasie nie saamgestem dat godsdienstige bewegings polities betrokke moet raak nie (bl 36). Die verslag noem self later, wanneer die swart onafhanklike kerke bespreek word, die verskynsel dat 'n godsdiens met weinig sosio-politieke belangstellins of pretensies, maar met 'n gerigtheid op die individuele religieuse behoeftes van sy aanhangers, deur hulle as genoegsaam en bevredigend ervaar kan word (bl 48).

Verder, 'n godsdiens wat deur sy aanhangers irrelevant ervaar word (al is dit net in sekere opsigte), bevat daarin reeds die saad vir verandering tot groter relevansie. Wat sal 'n mens egter van 'n godsdiens of kerk kan sê wat vir sy aanhangers relevant is (dalk vanweë ' $n$ beperkte werklikheidsbesef), maar vir buitestaanders, soos byvoorbeeld die navorser, in vele opsigte irrelevant? Dit blyk dus dat die begrip 'relevansie' self van beperkte relevansie in so ' $n$ studie is.

\section{- Godsdiens en maatskappy}

Hoewel 'n mens sou meen dat godsdiens die gemeenskap en gemeenskapsopset bepalend behoort te beinvloed, gebeur dit in die praktyk dikwels andersom. Die rede hiervoor is dat daar in die gemeenskap ook ander kragte aan die werk is, soos groepsbewussyn, groepsdina- 
miek, ideologiese motiewe en dies meer, wat dikwels so sterk is dat die godsdienstige element meegesleur word (soms juis vanweë die nuttigheid van godsdiens as legitimeerder).

Godsdienstige simbole speel ' $n$ wesenlike rol in die praktyk en lewe van 'n godsdiens. ' $n$ Simbool se eerste doel is om na 'n bepaalde waarheid of stelling te verwys. 'n Simbool kan egter so met bepaalde motiveringsentimente ('motivational feelings') geassosieer word dat dit daarna ook verwys. Soms kan hierdie tweede funksie primêr word. Waar die meeste motiveringsentimente belangrike sosiale implikasies het, spreek dit vanself dat godsdiens in praktyk en lewe 'n geweldige invloed binne die verband van 'n plurale samelewing kan uitoefen.

- Ambivalente verhouding van godsdiens met samelewing

Die gedagte wat vroeër uitgespreek is, naamlik dat godsdiens gesonde sosiale verhoudinge in die hand behoort te werk, word hier verder gevoer: 'Within the framework of values they (religious symbols) establish it can become possible for social debate to take place in a constructive way, using the religious matrix as a touchstone for conciliation' (bl 12). Dit word toegegee dat so 'n 'utopiese' situasie selde aangetref word en dat godsdiens dikwels al 'n diepgaande verdelende rol in samelewings gespeel het. Laasgenoemde word dan as 'siek' getipeer. In Suid-Afrika het ons ' $n$ handboekvoorbeeld daarvan dat godsdienste ook verdelend kan werk en dat 'n reeds kritieke situasie so vererger word.

Die volgende opsies word dan oorweeg:

- Verban godsdiens.

- Dwing alle Suid-Afrikaners om aan dieselfde godsdiens te behoort.

- Hoop dat institusionalisering godsdiens so sal verstar dat dit totaal irrelevant sal raak.

- Ontwikkel 'n oorkoepelende 'burgerlike godsdiens' wat almal sal saambind ongeag hulle godsdienstige verskille.

Daar word vervolgens gesê dat een van die aanduidings dat tussengroepverhoudinge in Suid-Afrika kritiek geraak het, die feit is dat navorsing getoon het (hoofstuk 3) dat nie een van hierdie opsies meer haalbaar is nie. Hierop sou ons kommentaar dadelik wees dat nie een van die genoemde opsies in elk geval werklike opsies verteenwoordig nie. Die afleiding dat die nie-realiseerbaarheid daarvan in Suid-Afrika dui op die kritiekheid van die situasie, is dus onsinnig. 
Een van die redes waarom godsdiens verdeling in die hand kan werk, is dat dit in diens gestel kan word van die belange van ' $n$ sekere groep tot benadeling van ander. Die verslag praat hiervan ' $n$ as 'undesirable phenomenon'. Hier sien ons een van die fundamentele funksies van godsdiens: identifisering en legitimering. Later word na die effekte onder andere daarvan verwys en dan word gesê: 'The harmful potentials described above and often seen in die functions of institutional religion are not, we believe, of the essence of religion' (bl 13). Dit is 'n duidelike voorbeeld van die normatiewe godsdiensbegrip waarmee die Werkkomitee gewerk het. Gewone praktiese norme wat bepaal is deur wat die Werkkomitee geag het in belang is van beter tussengroepverhoudinge in Suid-Afrika, het hierby gegeld. Hoe eerbaar sulke oorwegings ook al mag wees, is dit baie moeilik om hulle te versoen met die aanspraak dat ' $n$ wetenskaplike benadering van godsdiens gevolg is.

Een van die ingewikkeldste godsdienstige verskynsels is dié van religieuse identifikasie en legitimering. Die lAHR (Internasionale Genootskap vir Godsdienswetenskap) het kort tevore sy jaarlikse byeenkoms aan dié onderwerp gewy. Dit raak die kern van die probleem van tussengroepverhoudinge. Die identifiseringsfunksie van godsdiens werk veral in twee rigtings. Dit help om die identiteit van die eie groep te vestig (byvoorbeeld die van Jode onder verskillende nasionaliteite) en dit het ' $n$ bepalende invloed op die persepsies van die werklikheid (wat ander groepe insluit) deur lede van die groep. Dit geld vir alle godsdienste, maar die verslag meen hierdie verskynsel op 'n besondere en onheilspellende wyse in Suid-Afrika te sien funksioneer.

\section{KONFLIKTERENDE PERSPEKTIEWE EN GODSDIENS IN SUID- AFRIKA}

Hierdie uiters aktuele onderwerp word in hoofstuk 3 behandel, wat dit myns insiens dalk die belangrikste hoofstuk in die verslag maak. Die volgende sake is ter sake:

- Die aanwending van godsdiens om sosio-politieke posisies in SuidAfrika te betoog (Afrikaanse burgerlike godsdiens, Swart bewussyn en -Teologie).

- Godsdiens en identiteit.

- Die breë, algemene funksie en rol van godsdiens.

- Die bepaling van toekomstige moontlike houdings en optrede van godsdienstige groepe. 
- Individuele en gemeenskaplike godsdiens in spanning.

- Suid-Afrika, 'n samelewing sonder 'n godsdienstige meerderheid.

Een van die groot gevare wat die verslag in Suid-Afrika vrees, is dat die huidige konflik 'n godsdienstige dimensie kan verkry en dat dit so kronies kan word (soos in Noord-Ierland en Libanon). Dit kan maklik aangetoon word dat daar in Christelike verband alleen reeds ' $n$ groot verskeidenheid van maniere bestaan waarop die situasie beleef en verstaan, en moontlike oplossings bedink word. In plaas daarvan dat godsdiens, ook die Christendom wat vir die meerderheid mense in Suid-Afrika as gemeenskaplike godsdiens geld, mense oor grense heen bymekaarbring, werk dit verdelend. Groepsbelange en -standpunte word gelegitimeer en so absoluut gemaak.

Die vernaamste wyses waarop godsdiens vandag in Suid-Afrika ingespan word om sosio-politieke posisies en groepsbelange te verdedig, vind ons, volgens die verslag, in Afrikaanse burgerlike godsdiens en Swart Teologie. In beide gevalle word gebruik gemaak van mitifisering van eie geskiedenis of kollektiewe ervaring as kragtige meganisme om identiteit te bou en te motiveer. Die skerpste godsdienstige aanklag is wanneer apartheid as ' $n$ kettery verklaar word. Daarteenoor ervaar blankes ewe diepgaande probleme met die wyse waarop swart teoloë en kerklikes God vir die arme en onderdrukte toeëien en barbaarse geweld met teologiese en godsdienstige argumente probeer wettig (my formulering). Verontrustend is die geweldige afstand tussen die twee teenoorgestelde posisies.

' $n$ Onbekende faktor in hierdie verband is die inheemse swart onafhanklike kerke wat tussen die afgelope twee bevolkingsensusse 'n geweldige groei openbaar het, sodat hulle vandag verreweg die grootste godsdienstige groep in Suid-Afrika uitmaak. Hoe hierdie groepe hulle sosio-politieke posisies sien en godsdienstig definieer, is onduidelik, aangesien hulle oënskynlik nie-polities ingestel is. Baie respondente uit dié kamp het hulle tevredenheid uitgespreek met die sosiopolitieke posisies van aktivistiese swart kerkleiers, maar was erg daarop teë dat kerke, onder andere hulle eie, by politiek betrokke met raak. Die eksplosiewe groei van hierdie groep hou vir swart kerkleiers en swart kerklike groepe met politieke interesse en aspirasies ' $n$ wesenlike bedreiging in.

As identifisering en legitimering in ' $n$ homogene gemeenskap ingewikkeld is om te verstaan, is dit veel meer so in 'n plurale gemeenskap soos Suid-Afrika met sy verskillende godsdienstige groeperinge. In so 
'n opset word die individuele identifiseringsfunksie van godsdiens kardinaal geag, met ander woorde die wyse waarop individue hulle posisie, standpunte en toekomsvisie van tyd tot tyd vir hulleself uitmaak. Hulle doen dit hoofsaaklik deur te let op die oortuigings en waardes van bepaalde leierspersoonlikhede en die rigting waarin groepe beweeg. Daarom is dit belangrik dat die oortuigings en waardes van persone en groepe met wie individue identifiseer, moet integreer. Godsdiens speel ' $n$ belangrike rol om sodanige integrasie te bewerkstellig. Wanneer godsdienstige groepe doelbewus 'n politieke betrokkenheid vermy en hulle oriënteer aan die individuele religieuse behoeftes van hulle lede, soos in die geval van pinkstergroepe en die swart onafhanklike kerke, kan dit daarop dui dat daar soveel uiteenlopendheid en spanning in die samelewing bestaan dat integrasie regdeur nie meer moontlik geag word nie. Die klein groepie word as 't ware 'n eie wêreldjie.

Die verslag ag die swart onafhanklike kerke die vernaamste onbekende faktor wanneer toekomstige houdings en gesindhede van godsdienstige groepe in Suid-Afrika voorspel moet word. As hulle nie-politieke oriëntasie as 'n soort askese geinterpreteer kan word, beteken dit moontlik dat daar 'n yslike latente frustrasie bestaan met 'n samelewing wat nie toelaat dat al die funksies van godsdiens (onder andere persoonlik, sosio-polities en burgerlik) na vore kom nie (bl 59) en dat hulle gevolglik ook die potensiaal inhou om êrens vorentoe 'n sterk sosio-politieke rol te begin speel. Aan die ander kant is daar in die godsdiensgeskiedenis verskeie voorbeelde van godsdienste wat hulle net op die individuele religieuse behoeftes van hulle lede rig en na dekades (in enkele gevalle eeue) nog geen inklinasie toon om daarvan af te wyk nie.

Wanneer toekomstige godsdientige gesindhede en houdings voorspel moet word, moet daar ook gekyk word na 'n meningspeiling wat prof GC Oosthuizen en 'n span ondersoekers in die Durbanse metropolitaanse area uitgevoer het en wat aanhangers van wye spektrum godsdienste en kerke betrek het. Hieruit blyk dat hoewel die meeste respondente geen probleem gehad het met die gedagte dat anderskleuriges of persone van ander kultuur saam met hulle aanbid nie, hulle ernstige bedenkinge gehad het oor veelrassige onderwys. Verder het dit geblyk dat die meerderheid respondente uit elke groep ten gunste is van die handhawing van etniese identiteit, hoewel hulle nie ten gunste van staturêre handhawing daarvan is nie. Na aanleiding hiervan en ander gegewens word gekonkludeer dat etniese identiteit die sterkste 
ervaar word, sterker as religieuse en rasse-identiteit, en dat laasgenoemde twee hoogstens as bydraende faktore tot etniese identifikasie dien (behalwe in die geval van die Moslems vir wie die religieuse die sterkste geweeg het). Verder voorspel die verslag dat wanneer veelrassige onderwys en godsdiensoefening algemeen ingevoer sou word, bepaalde spanningsfaktore wat tans onder die oppervlakte leef, na vore sal tree (bl 49 e v). Die huidige aparte samelewingstrukture onderdruk dus die verwerkliking van sulke spannings. Aan die ander kant laat dieselfde samelewingstrukture toe dat groepsidees en -verwagtinge groei en opbou tot die punt waar dit al moeiliker word om hulle met mekaar te versoen of te integreer in nasionale belang (bl 51 en 53).

Baie mense wat tans om 'n unitêre staat en samelewing pleit, het klaarblyklik self nie 'n duidelike nasionale toekomspersepsie nie. $\mathrm{Na}$ aanleiding van die meningsopname van Oosthuizen en medewerkers word voorspel dat baie sulke mense 'n onaangename verrassing gaan kry wanneer so 'n gemeenskap sou realiseer, omdat tradisionele en individuele identiteite onder druk gaan kom. Identiteitspannings wat tans latent is, gaan dan na vore kom en die eindresultaat sal waarskynlik'n gemeenskap wees wat weer eens uit verskillende groepe saamgestel is, sy dit dan langs ander lyne en met ander grense (bl 58). Baie mense weet danig goed wat met die huidige samelewing- en politieke strukture verkeerd is, maar daar is bitter min mense wat ' $n$ duidelike beeld het van wat hulle in die plek daarvan wil hê en wat die volle implikasies van so' $n$ alternatief sal wees (bl 57).

Dit blyk dat die debat oor die toekoms van Suid-Afrika, soos in die media berig en wat op nasionale vlak geskied, vir die meeste mense en groepe iets abstraks is waarvan hulle die implikasies nie in hulle individuele situasies kan realiseer nie. Dit staan ietwat in kontras met die beroepe wat in die debat vir geregtigheid in die konkrete situasies gedoen word. Hierdie verskynsel blyk onder andere in die polêre spanning waaraan kerkleiers onderwerp word: Soos verwag kan word, gaan dit vir hulle om waarheid en geregtigheid in die groter verband. Tog blyk uit hulle optrede en uitsprake dat hulle ook sensitief is vir die verwagtinge van lokale groeperinge (byvoorbeeld gemeentes) en dat hulle nie altyd weet hoe om nasionale en lokale belange by mekaar te bring nie (bl 54).

Studies oor persepsieverskille het aangetoon dat daar in Suid-Afrika ' $n$ wye persepsiespektrum oor waardes en werklikheid bestaan. Dit hou verband met ' $n$ wye spektrum van godsdiens-etiese opvattings wat op hulle beurt gewoonlik weer inpas by groepsoriëntasies. Hierdie 
spektrum word al wyer namate polarisasie toeneem wat op sy beurt verband hou met toenemende frustrasie en verbittering aan die een kant, en bekommernis en gesindheidsverharding aan die ander kant. Dit word as tragies beskou dat godsdiens in sommige gevalle hierdie polarisasie aanhelp en legitimeer. Die wese van etiek lê immers digby die fundamentele religieuse ervaring en visie wat altyd ook die grootste werklikheidsraamwerk en interesse in die oog moet hou.

Suid-Afrika is ' $n$ samelewing wat uit minderhede saamgestel is. Dit geld ook op godsdienstige vlak, want ofskoon die Christendom 'n oorweldigende meerderheid vertoon, is dit verdeel in ' $n$ menigte van minderheidskerke wat elkeen ' $n$ eie selfstandige bestaan voer. ' $n$ Minderheidsgroep en hulle godsdiens het tot dusver die toneel gedomineer en die kanse is goed dat selfs wanneer die magsbalans verander of omvergewerp sou word, ' $n$ ander minderheidsgroep hierdie posisie sal oorneem. Die gevaar is wesenlik dat godsdiens 'n gevangene word van groepsbelange en -verwagtinge. Die verslag stel dit as 'n saak van dringende erns dat godsdiens in hierdie land geöntideologiseer en gedeabsoluteer sal word en wel in die sin dat opgehou sal word om die normerende funksie van godsdiens in te span vir die legitimasie van seksionele belange-aansprake wat die groter algemene welsyn en interesse misken. ' $n$ Probleem wat hier voorsien word, is dat daar nie 'n gemeenskaplike stel simbole bestaan aan die hand waarvan nasionale interesse, verwagtinge en ideale uitgespel en ' $n$ nasionale waardesisteem opgebou kan word nie. Binne die Christendom het daar selfs verwydering op dié punt gekom met die opkoms van 'n swartbewussynsteologie wat teenoor die teologie van die Afrikaanse kerke stelling inneem. Die verslag spreek nogtans die hoop uit dat so iets uiteindelik moontlik sal wees.

\section{DRINGENDE AKTUALITEITE}

Die volgende hoofstuk (4) handel oor dringende aktualiteite in die huidige openbare debat. Die volgende sake word bekyk:

- Menseregte en die kerklike debat daaroor in Suid-Afrika (navorser prof DA du Toit).

- Mag, geloofsoortuigings en billikheid (navorser prof K Nürnberger).

- Die probleem van geweld.

'n Harde woord word oor eersgenoemde saak aan die adres van die Afrikaanse kerke gerig. Die stelling word gemaak dat dié kerke nage- 
laat het om hulle lidmate bewus te maak van die noodsaak dat 'n gemeenskap op basiese humane waardes gebaseer moet word, waarvan die belangrikste die van menswaardigheid is. Blankes en veral Afrikaanssprekendes is erg onsensitief vir die lyding wat huidige maatskaplike strukture vir anderskleuriges meegebring het (bl 107).

Ons kyk kortliks ook na gegewens wat uit meningspeilings oor die onderwerp van geweld verkry is:

Gevra oor die noodsaak van protesaksies wat met lewensverlies gepaard mag gaan, het die verskillende groepe soos volg geantwoord: Blankes $92,1 \%$ daarteen; Kleurlinge $72,9 \%$ daarteen en $11,9 \%$ daarvoor; Indiërs $74,5 \%$ daarteen en $12,9 \%$ daarvoor. Gevra of geweld gebruik mag word om politieke oogmerke te bereik, was die antwoorde soos volg: Blankes 70,1\% daarteen; Kleurlinge $62,5 \%$ daarteen; Indiërs $59,8 \%$ daarteen; Swartes $36,6 \%$ daarteen; $30,9 \%$ daarvoor onder sekere omstandighede en $14,4 \%$ daarvoor in enige omstandighede. Hieruit word die gevolgtrekking gemaak dat feitlik die helfte van die swart deel van die bevolking meen dat geweld op een of ander wyse vir verandering ingespan mag word en dat dit nie onversoenbaar met hulle godsdienstige oortuigings is nie.

Hierteenoor het ook 'n sekere mate van optimisme geblyk. 79,1\% van die Kleurlinge en $79,9 \%$ van die Indiërs was van mening dat tydige verandering in die land sonder die druk van geweld wel moontlik is. Gevra of tussengroepverhoudinge binne die volgende vyf jaar gaan verbeter, het die verskillende groepe hierop soos volg bevestigend geantwoord: Kleurlinge $68 \%$, Indiërs $64,9 \%$, Blankes $48,3 \%$ en Swartes $47,6 \%$.

Hoofstuk 4 maak fassinerende leesstof uit. Uitmuntende studiestuk$\mathrm{ke}$ is daarin verwerk. Die meeste daarvan het reeds in een of ander vorm in publikasie verskyn. Ongelukkig laat die omvang van hierdie bespreking ons nie toe om daaroor ook te handel nie.

\section{WERKKOMITEE SE AANBEVELINGS}

In die laaste hoofstuk gaan dit om die Werkkomitee se bevindinge waarvan ons sommige hierbo reeds behandel het en aanbevelings waarna ons vervolgens kyk en wat aan bepaalde adresse gerig word.

Aan die Hoofkomitee word min of meer die volgende gerig: Tot nou toe het die rol wat godsdiens speel in die bepaling van tussengroepverhoudinge onvoldoende aandag ontvang. Godsdiens is in hierdie opsig 
ambivalent deurdat dit mense tot verbetering van tussengroepverhoudinge kan motiveer, maar net so wel kan bydra tot die verabsolutering van groepsidentiteite en dus verdelend kan werk. Meer studie, veral multidissiplinêre studie, is nodig om hierdie funksies van godsdiens beter be begryp.

Godsdienstige gemeenskappe (soos kerke) word soos volg aangespreek: Oorweeg noukeurig die bevindinge van hierdie verslag en probeer om godsdiens en die rol van die kerk binne die groter SuidAfrikaanse konteks te sien. Ofskoon die respondente oor die algemeen gevoel het dat godsdiens beter tussengroepverhoudinge behoort te bevorder (tot $84 \%$ van sekere groepe respondene), het gemiddeld slegs $37 \%$ geglo dat godsdiens of die kerke daartoe in staat sal wees. 'n Vername wyse waarop kerke kan begin om die impasse van groepsgeoriënteerde godsdiens te deurbreek, is om in eie kring te begin om oor basiese menseregte te praat en wat dit moet behels, en later tussenkerklik die debat verder te voer. Verder moet kerklike bediening nie alleen daarop ingestel wees om mense se vrese in veranderende omstandighede te besweer nie, maar ook om hulle met toekomshoop en idealisme te inspireer. 'n Onttrekkingsgodsdiens gaan min voordeel meebring. Kerke en godsdienste moet daarop bedag wees om in tye van konflik groepsposisies, -persepsies en -ideologieë te legitimeer en eerder strewe na die daarstelling van 'n gemeenskaplike waardesisteem wat vir Suid-Afrikaanse gemeenskap in die geheel in hierdie tyd van krisis kan dien as motivering om die gemeenskaplike belang na te streef. Aangesien onbekend onbemind maak, moet kerke probeer om meer van geloofsgenote in ander groepsverbande te wete te kom en konstruktiewe interaksies te weeg te bring.

Dit het duidelik geword dat die samelewingsituasie en politieke opset in Suid-Afrika so ingewikkeld geword het dat kerke ò nie meer 'n duidelike beeld het van hoe hulle hulle profetiese rol teenoor die staat moet vervul nie of in argaïese paradigmas vasgehaak het. Kerke sal hulle nou meer as ooit sal moet vergewis wat die verhouding kerk en staat inhou.

Die akademiese gemeenskap word deur die Werkkomitee opgeroep om die uitdaging van onontginde navorsingsgebiede wat hierdie verslag aan die lig gebring het, nie te ignoreer nie.

Politieke besluitnemers word soos volg aangespreek: Dat polarisasie tussen groepe in Suid-Afrika 'n gevaarpunt bereik het, blyk ook uit hierdie studie waar primêr op godsdienstige groepe gefokus is. Owerheidsinstansies moet kennis neem van die ambivalente wyse waarop 
godsdienste met betrekking tot tussengroepverhoudinge kan funksioneer. Onafhanklike swart kerke behoort met meer simpatie deur die owerheid behandel te word. Godsdiensvryheid moet gehandhaaf bly en die een godsdienstige groep moet nie bo die ander deur die owerheid bevoordeel word nie. Wet en orde kan net op die grondslag van geregtigheid gehandhaaf bly.

Soos reeds genoem, volg hierna verskeie aanhangsels, elkeen 'n lesenswaardige dokument in eie reg, en die verslag word afgesluit deur 'n uitgebreide lys van publikasies wat handel oor tussengroepverhoudinge in Suid-Afrika en wat verskyn het in die tydperk 1900-1984. Die nuttigheidswaarde van die verslag word so aanmerklik verhoog. Die Werkkomitee het getoon dat hy, naas verslaggewing aan die Hoofkomitee, ook die stimulering van voortgaande navorsing op hierdie hele veld in gedagte gehad het. Persoonlik het ek die behoefte na 'n saakregister ervaar, vanweë die feit dat sommige aangeleenthede in verskillende kontekste herhaal word en 'n mens graag sou wou nagaan hoe dit gehanteer word. Dit sou die wetenskaplike nuttigheid van die verslag verhoog het.

\section{EVALUASIE}

Naas die evaluerende opmerkings wat in die loop van hierdie bespreking gemaak is, wil ek my graag die volgende opmerkings veroorloof. Dit moet egter duidelik gestel word dat die verslag so omvangryk en uitgebreid is, dat ' $n$ mens in ' $n$ groot mate gedwing word om oorsigtelik te praat.

Wat wetenskaplikheid betref, kan 'n mens nie anders as om weer met waardering melding te maak van die uitgebreide en goeie navorsing wat in hierdie studie en verslag ingeploeg is nie. ' $n$ Groot bydrae is gelewer en dit is moontlik dat die verslag ' $n$ vername stimulus gaan blyk te wees in die navorsing van die vele onontginde gebiede wat uitgewys is en om diegene te motiveer wat met nuwe navorsing die verslag verkeerd wil bewys. Of hierdie verslag alleen of saam met die ander verslae geneem word wat deel uitgemaak het van die groot projek oor tussengroepverhoudinge, bly dit onbetwisbaar 'n kragtoer waarop die RGN en sy medewerkers trots kan wees.

Nadat ' $n$ mens dit gesê het, bly dit 'n vraag by watter genre ons die verslag sal indeel. Uit wat ons in die loop van die bespreking gesê het, het dit duidelik geword dat ons hier nie met 'n wetenskaplike bestudering van godsdiens in die objektief analities-deskriptiewe sin te 
doen het nie, al word baie van godsdienswetenskaplike terme en teorieë gebruik gemaak. Daarvoor weerspieël dit te veel voorafingenome waarde-oordele en word daar te normatief-evaluerend met sake omgegaan. Myns insiens is die bepalende inslag van hierdie stuk teologies, of, om meer spesifiek te wees, natuurteologies.

Ek meen dat dit 'n billike vraag is of die verslag nie 'n groter impak sou gehad het as dit dan eerder 'n Christelik-teologiese inslag sou gehad het nie. Die verslag noem self dat die Christendom verreweg ' $n$ oorheersende groep in die Suid-Afrikaanse samelewing uitmaak en 'n mens kry die indruk dat, dikwels wanneer oor 'godsdiens' gepraat word, eintlik die Christendom bedoel word. Baie van die waardes wat uit waarde-oordele spreek, is ò kripto-Christelike waardes of is met Christelike standpunte versoenbaar. Met die natuurteologiese inslag wat die komitee gekies het, is die probleem dat almal aangespreek word en uiteindelik ook niemand spesifiek aangespreek word nie. In die verslag word verwys na adreslose teologie wat nooit daartoe kan kom om die praktiese implikasies van wat dit betoog, uit te spel nie. In 'n sekere sin geld dit ook vir die verslag self. Sou die komitee 'n Christelik-teologiese benadering gekies het, sou dit in staat gewees het om baie pertinent tot Christene en kerke te spreek.

Vanweë die godsdienswetenskaplike styl van argumentering en taalgebruik mag dit verder so wees dat baie teoloë dit nie 'n maklike boek sal vind om te volg of te verteer nie. Wanneer daar byvoorbeeld oor die legitimerings- en identifiseringsfunksies van godsdiens gehandel word, help dit byvoorbeeld om die godsdienswetenskaplike agtergrond van dié teorieë te ken, iets wat vir die meeste teoloë onbekend is.

Dit kom dus ook daarop neer dat die metodologiese aspek van die verslag moontlik as die mees kritiseerbare aspek daarvan uitgewys kan word. Hierby kom ook die onverfynde pragmatiese godsdiensopvatting waarna ons vroeër verwys het.

Sulke kritiek maak die verslag egter nie onwetenskaplik, irrelevant en onbelangrik nie, veral nie vir kerke en teoloë nie. Elke teoloog, kerkleier en kerkman vir wie die rol van die kerk en koninkryk in SuidAfrika erns is, behoort hierdie verslag met nougesetheid te bestudeer. Hulle sal met stellings en vrae kennis maak waarvan hulle dalk nie gaan hou nie, maar waarvan hulle op die lang duur ook nie sal kan ontsnap nie. 